$$
\begin{gathered}
\text { Colloquia Litteraria } \\
\text { UKSW } \\
62009
\end{gathered}
$$

KLARA LESZCZYŃSKA

\title{
NARRACJA W HISTORII IGNACEGO KRASICKIEGO
}

\section{Narrator}

Historia Ignacego Krasickiego niewątpliwie jest w dorobku literackim autora powieścią wyjątkową. Pozornie wydaje się, że nie różni się od pozostałych - fikcyjny narrator w pierwszoosobowej formie przedstawiający własne doświadczenia, moralizatorsko-dydaktyczny charakter, gatunkowe zbliżenie do pamiętnika (historia życia). Wystarczy jednak uważniej przyjrzeć się przedstawianiu przestrzeni, stosunkowi do odbiorcy, sposobom mówienia o świecie, by zauważyć, że wszystko jest nowe - inny niż we wcześniejszych utworach jest adresat dzieła, a nadawca zupełnie inaczej się do niego odnosi, inne mu stawia wymagania; rzeczywistość też jest nie ta sama, mniej „dotykalna" i swojska niż w Panu Podstolim, mniej istotna niż w Mikołaja Doświadczyńskiego przypadkach. Znika świat szlachecki, zastąpiony przez otchłań dziejów, korowód ludzi i zdarzeń, literatura i prawda znów przeplatają się ze sobą. Żeby podołać zadaniu analizy figury narratora i jego czynności, przyjrzyjmy się kolejno różnym poziomom konstrukcji, jaką jest ostatnia z powieści Księcia Poetów.

\section{Wydawca}

Pierwszą instancją nadawczą, z którą styka się czytelnik, jest autor Przedmowy, a właściwie krótkiej notki na początku, dwóch uwag i jednego przypisu, w którym określa się mianem edytora manuskryp- 
$t u$ - jest to zreszta jedyna autotematyczna informacja, jaką podaje. Na podstawie jego wypowiedzi można wyodrębnić jeszcze kilka najwyrazistszych cech jego osobowości:

Między Biłgorajem a Tarnogrodem jest karczma w lesie; w tej gdy na popas stanąłem, postrzegłem siedzącego na podsieniu Kozaka, który gdy mu zgasł tiutiun, poszedł do stajni i stamtąd zwinięty papier w trąbkę wyniósłszy zapalił go od końca, a przyłożywszy do lulki, gdy zagasły ogień rozniecił, rzucił papier na ziemię, sam wsiadł na konia i pojechał. Że reszta papieru nie dogorzała, podniosłem go i w małym, który się został kawałku, przeczytawszy te słowa: „Gdyśmy się więc przeprawiali przez rzekę, obróciwszy się Lech do sw...", chcąc wiedzieć, co dalej następowało, pobiegłem na owo miejsce, gdzie Kozak chodził; tam w sienie pod żłobem znalazłem tę historią̨ ${ }^{1}$.

Są to przede wszystkim charakterystyczne dla kompetentnego i wiarygodnego badacza: dociekliwość i dokładność. W tym krótkim wstępie skrupulatnie wypisuje wszystko to, co wiąże się z jego znaleziskiem: miejsce - podane może niezbyt precyzyjnie, ale wyraźnie lokujące akcję w rzeczywistości pozaliterackiej i tym samym potwierdzające autentyczne istnienie odkrytego rękopisu; okoliczności - nieodznaczające się niczym niezwykłym, a tym samym również tworzące iluzję prawdy; czyni nawet wzmiankę wyjaśniającą jego tam obecność i odnotowuje pierwsze słowa (jak zauważył Wacław Walecki, niezbyt precyzyjnie, pomija bowiem zaimek wskazujący „tę"2). Wszystko to jest poszerzeniem popularnej w XVIII wieku konwencji nadawania powieściom pozoru prawdziwych dokumentów ${ }^{3}$. Prawda

\footnotetext{
1 Cyt. za: I. Krasicki, Historia, oprac. M. Klimowicz, PIW, Warszawa 1956. Wszystkie dalsze cytaty pochodzić będą z tego wydania (oznaczanego dalej I.K.H.) i dla wygody Czytelnika ich lokalizacja podana będzie w tekście głównym w kolejności: cyfra rzymska - numer części, arabska - rozdział i takoż - strona. Małe p na początku oznaczać będzie, że mowa o przypisie, wielkie - że o Przedmowie.

2 Por.: W. Walecki, Wieczny człowiek. „Historyja” Ignacego Krasickiego i jej konteksty kulturowe oraz literackie, Księgarnia Akademicka, Kraków 1999, s. 46-47.

3 Zabieg taki wykorzystał np. De Laclos w Niebezpiecznych zwiazkach, innym przykładem nadawania literackiej fikcji pozorów autentyczności była forma listów pisanych do rzeczywistego adresata, jaką nadał Diderot swojej Zakonnicy (na ten temat więcej w: M. Jasińska, Autentyzm i literackość a wiedza powieściowego narratora, „Pamiętnik Literacki” 1963, z.1.).
} 
i zgodność z rzeczywistością historyczną jest zresztą dla edytora ważna tak bardzo, że gdy padają słowa: ,[...] naszego książęcia Popiela Drugiego myszy zjadły" [III, 7, s. 162], nie może się powstrzymać od potwierdzenia wiarygodności rękopisu i zarazem przestrzeżenia łatwowiernych czytelników: „Jakiś poeta opisał tę straszną awanturę; czytałem ją, ale że pełna bajek ostrzegam, żeby mu nie wierzono" [p, III, 7, s. 162] $]^{4}$. Od razu poznać można prawdziwego człowieka oświecenia, niepodatnego na baśnie i zabobony, sądzącego świat wedle kryteriów rozumu, za pomocą szkiełka i oka, starannie sprawdzającego i odnotowującego inne źródła. Jest to niewątpliwie pierwszy w literaturze przykład (i wzorzec) dla dzisiejszych redaktorów i wydawców, szczególnie dzieł noszących piętno czasu. Skoro zaś o czasie mowa, ten temat w Przedmowie w żaden sposób nie jest poruszony, zakładać zatem należy, że wiarygodny jest rok wydania Historii jako moment nieznacznie późniejszy od jej znalezienia. Fakt nieobecności na okładce pierwszego wydania nazwiska Krasickiego również przyczyniał się do podtrzymania wrażenia autentyczności. Na pytanie, jakie jest zadanie Edytora Manuskryptu i jak przysłużył się on całemu dziełu, odpowiemy nieco później.

\section{Kwiat piwonii}

Drugi narrator, a raczej właściwy narrator i zarazem bohater opowiadanej przez siebie historii, nie sprawia aż takich kłopotów, mówi o sobie wprost: pochodzi z kraju Lugnagianów, urodzony w mieście Gangnapp i nazwany Grumdryppem (co tłumaczy się jako kwiat piwonii właśnie) należy do nielicznego grona nieśmiertelnych. Przez wiele lat prowadził normalne życie, później, po stracie ukochanej żony, samotny i niemogący znaleźć wspólnego języka ani z nowymi pokoleniami, ani z podobnymi sobie, wybiera się w góry, by odsunąć się od świata. Tam znajduje drzewko, którego żywica ma niezwykłą moc przywracania młodości. Od momentu dokonania tego odkrycia wędruje po świecie i przybierając coraz to nowe imiona, obserwuje, poznaje i ocenia cywilizacje, kultury i ludzi. Tyle jako postać.

\footnotetext{
4 Aluzja, oczywiście, do Myszeidy.
} 
Jako opowiadacz bynajmniej się ze swoją funkcją nie ukrywa. Przeciwnie, od samego początku zaznacza fakt tworzenia:

Tego jestem rodzaju ja, który przypadki życia mojego pisać przedsięwziąłem [I, 1, s. 43].

Służy temu również budowanie relacji nadawca - odbiorca, podkreślane za pomocą bezpośrednich zwrotów do czytelnika:

Nie będą mi mieli za złe czytelnicy, że sposób myślenia przyjaciela mego przytaczam [I, 17, s. 93];

Jeżeliby rzetelnej mojej powieści nie chcieli wierzyć czytelnicy, niech patrzą w rocznych dziejach Tacyta [p, II, 1, s. 119].

Co więcej, ujawnia się $\mathrm{w}$ autorskiej kompetencji wpływania na kształt tworzonego tekstu:

W tym miejscu niech mi się pozwoli zastanowić nieco czytelnik nad lekkomyślnością i zuchwałością kronikarzów [I, 2, s. 50];

Mijam cuda, poprzedzające urodzenie tego bohatera [I, 4, s. 54];

Jeśli chodzi o sytuację narracyjną, nie jest ona jasno określona. Nie ma żadnych przesłanek, które wyjaśniałyby, w jakich okolicznościach Grumdrypp podjął swoją pracę. Można jednak określić czas, w którym musiało to nastapić. Najpóźniejsze chronologicznie wydarzenie wspomniane w rękopisie to pojawienie się książki Józefa Andrzeja Załuskiego Programma literarium ad bibliophilos z 1732 roku, więc, jeśli poważnie potraktujemy Przedmowę do dzieła, musiała historia nieśmiertelnego powstać między 1732 a 1779 rokiem. Od początku opisywanych wydarzeń dzielą go zatem stulecia. Wykorzystuje niejednokrotnie ten szeroki horyzont, dowolnie przemieszczając się nie tylko pomiędzy czasem akcji a czasem narracji:

Przebywszy Ciaśninę Herkulesową stanęliśmy u portu Gades, któ ry teraz Kadyks zowią [wszystkie podkreślenia moje-K.L.]. [...] 
Po kilkudniowej podróży wjechałem między góry, które na ów c zas zwano Orospeda, teraz Sierra Morena [I, 9, s. 66];

lecz także robiąc retrospekcje (historia Neoklesa [II, 5]) oraz na rozmaite sposoby antycypując przyszłość (oczywiście przyszłość z punktu widzenia czasu akcji, a przeszłość - z płaszczyzny narracji): po pierwsze, przez anachronizmy:

[...] i na dobre mi to wyszło, żem się nie znajdował w stołecznym mieście, gdy jakem się wkrótce z gazet dowiedział, naszego książęcia Popiela Drugiego myszy zjadły [III, 7, s. 162];

po drugie przez ujawnianie swoich przyszłych planów:

Wiedział on klucz hieroglifików i bardzo mi wiele dawnych napisów [...] wytłumaczył. Zapisywałem je pilnie i całą relacją tej podróży mam jeszcze dotąd przy sobie. Wydam ją z czasem na świat [I, 6, s. 59-60];

po trzecie wreszcie, poprzez wybieganie w bliższą lub dalszą przyszłość od przedstawianych właśnie wydarzeń:

Późniejszymi czasy najpierwszy z Europeanów Marcus Paulus, Wenecjanin, dostawszy się tam a mieszkając w Pekinie, znalazł mój manuskrypt [...] Tych wszystkich okoliczności dowiedziałem się od samegoż Marka Pawła, gdym go za jego z Chin powrotem w Europie widział [II, 8, s. 144-145]

Miejsca, w którym toczy się „akcja” pisania, nie sposób zlokalizować, podobnie jak niewyjaśnione pozostają okoliczności, w jakich rękopis znalazł się między Biłgorajem a Tarnogrodem (choć niewątpliwie nie jest to dzieło przypadku). Nie sposób natomiast żywić jakichkolwiek wattpliwości co do celu narracji:

[...] ja, jako świadek oczywisty tych dziejów, mam to sobie za powinność, ażebym ile możności czytelników z błędu wywiódł powiedając szczerze, co się, jak i kiedy działo [I, 2, s. 48-49]; 
Temu, co widział i słyszał, najbezpieczniej wierzyć można [I, 4, s. 54].

Niejednokrotnie i na różne sposoby podmiot podkreśla swoją rolę naocznego świadka, tego, czyim zadaniem jest utrwalenie i zachowanie dotychczasowego dziedzictwa kulturalnego. Jednym ze sposobów uwiarygodniania swojej obecności przy najważniejszych opisywanych przezeń zdarzeniach, jest podawanie szczegółów, które znać może tylko ktoś, kto widział je własnymi oczyma:

Attal nie był podobny do Aleksandra, wzrostu był wyższego, ospowaty i miał brodawkę na nosie, która go mocno szpeciła [I, 2, s. 50];

Również dbałość o prawdę i drobiazgowość ${ }^{5}$, niezwykle wręcz podobna do tej, jaka cechowała edytora, potwierdzają jego status bezpośredniego obserwatora i uczestnika wydarzeń:

Pisze Kurcjusz, iż wojska Porusowego było 30000 pieszych; było nas tylko 22 000; słoniów 85, było tylko 32 [I, 2, s. 49];

Powołuje się też na liczne dokumenty, które co prawda nie dotrwały współczesnych czytelnikom czasów, stały się jednak dla narratorabohatera źródłem wiedzy, którą przekazuje:

Pisał Ptolomeusz diariusz życia Aleksandrowego, ale że był szczery, nie wyszedł na świat. Po śmierci jego dostałem kopii i stąd najwięcej powziąłem wiadomości i lepiej, niżeli gdym na żywego patrzył, poznałem Aleksandra [I, 5, s. 22].

To zastrzeżenie wyjaśnia zresztą znajomość faktów sprzed spotkania Grumdryppa z Macedończykiem, które niejednokrotnie przywołuje, choćby te dotyczące jego wychowania i młodości. Z archiwum Ptolomeusza pochodzi jeszcze jeden „dokument”, na który powołuje się opowiadacz, a nawet dokładnie go cytuje: miany.

Innym przykładem skrupulatności narratora jest dokładne określanie każdej daty prze- 
Między innymi korespondencjami kancelarii królewskiej znalazłem był [...] list, za którym Arystoteles do dworu Filipa był sprowadzony [...] był zaś takowy: „Z zlecenia królewskiego donoszę ci, iż jesteś wyznaczony nauczycielem młodego królewicza. Jurgieltu będziesz miał dwa talenty, stół u dworu, mieszkanie i oprócz tego wszystkie inne wygody. [...] Bądź zdrów." [I, 4, s. 55].

Jest to jedyny przypadek przytoczenia co do słowa fałszywego dokumentu. Powodem takiej decyzji była polemika zjedną z legend związanych z filozofem, według której Filip cieszył się bardziej z tego, że syn urodził się w czasie życia Arystotelesa, niż z samego faktu posiadania syna. „Autentyczny” list w sposób oczywisty służy podważeniu prawdy tej opowieści. Na marginesie rozważań o dokumentach warto wspomnieć, że raz zdarza się, że prawdziwość słów Grumdryppa poświadcza rzeczywisty dokument:

Jeżeliby rzetelnej mojej powieści nie chcieli wierzyć czytelnicy, niech patrzą w rocznych dziejach Tacyta, w rozdziale 42 księgi 13, co ten w ustach Suiliusza, na którego Seneka instygował, kładzie: „Nec Suilius quaestu [...] etc." [p, II, 1, s. 119].

Wreszcie skrupulatne zaznaczanie własnych ,śladów” w historii ma poświadczać rzeczywiste istnienie w niej narratora, a są to zwykle ślady niebagatelne - zachowanie dla potomności listów Cycerona [I, 21, s. 108] oraz wielu innych ważnych dzieł starożytnych, między innymi poematów Wergiliusza i Horacego [III, 8], wiadomości o właściwościach roślin, których części udzielił już ówczesnym ludziom nauki [II, 10] i kilka innych, nad którymi zastanowimy się później. Trzeba jeszcze wspomnieć o zasługach narratora-bohatera dla onomastyki polskiej:

[...] tam, idąc po stopniach, zostałem rotmistrzem i w nadgrodę zasług dana mi była osada, którą nazwałem Koninem dla dobrej paszy i łąk rozległych. Miasto to trwa dotąd i wraz z okolicą jest starostwem [III, 6, s. 158-159]. 
Zdawać by się mogło, że wszystkie te zabiegi służą stworzeniu iluzji rzeczywistości, tak jak działo się to w innych powieściach Księcia Biskupa. Jednak w istocie dzieje się na odwrót. Narrator jako naoczny świadek historii jest niewiarygodny i bynajmniej nie jest to niezgodne z intencją autorską. Już wymienione wyżej zabiegi - skrupulatność, dokładność, wykłócanie się z kronikarzami o szczegóły - stają się parodią naukowości, ścisłości i wierności historycznej prawdzie. I o ile wiele argumentów mimo to zachowuje swoją wagę, o tyle część z nich staje się jedynie literacką grą, zabiegiem służącym wręcz wywołaniu komicznego efektu (trudno brodawkę traktować jako poważny dowód na niesłuszność twierdzeń kronikarza). Jednak autorytet Grumdryppa jako przekaziciela bezwzględnej prawdy historycznej zburzony zostaje znacznie wcześniej, zanim jeszcze on sam zostanie dopuszczony do głosu. Dzieje się tak, ponieważ Przedmowa do dzieła również nie spełnia swojego zadania, a może raczej spełnia je w przewrotny sposób. Krasicki wykorzystuje chwyt z założenia uwiarygodniający dzieło literackie jako chwyt właśnie, jako ograną konwencję, która świadczy wyłącznie o literackim charakterze utworu. Nie bez przyczyny zresztą pierwsze słowa jego powieści odwołują się do Swifta, który w Podróżach Guliwera zastosował podobny zabieg w tym samym celu. Co więcej, XBW, jakby mu było mało, wykorzystuje do cna wszystkie możliwości, jakie ta konwencja otwiera. Wydawca w swojej ścisłości i drobiazgowości, podobnie jak narrator powieści, kompromituje sam siebie i starając się udowodnić prawdziwość swojego manuskryptu, podkreśla jeszcze jego fikcyjny charakter. Zaś jego dbałość o źródła staje się pretekstem do literackiej zabawy i stworzenia związków między różnymi tekstami. Zresztą sam sposób, w jaki kończy swoją Przedmowę, powinien wzbudzić w czytelniku wątpliwości, bowiem w słowach:

Kto by się spodziewał takiego skarbu między Biłgorajem a Tarnogrodem? [P, s. 41]

pobrzmiewa niespodziewanie silna ironia. 
Również pochodzenie narratora nie przyczynia się bynajmniej do stworzenia wrażenia wiarygodności. Jego korzenie sięgają przecież innej fikcji literackiej, pokrewnej już choćby tym, że świat w niej przedstawiony również rościł sobie pretensje do bycia rzeczywistym tak, by nikt nie miał wattpliwości, że takim nie jest. Kontynuuje zresztą Książę Biskup grę dziekana kolegiaty św. Patryka, Grumdrypp powołuje się na nią jako na źródło historyczne, można zatem powiedzieć, że oba teksty poświadczają się i demaskują jednocześnie. Baśniowy motyw „magicznej” rośliny, dzięki której bohater się odmładza, także wskazuje na dystans, jaki powinien mieć do niego czytelnik, przede wszystkim ze względu na nieprzystawalność tak niepoważnej motywacji do poważnych założeń powieści (wędrówka bohatera w czasie i przestrzeni nie służy bynajmniej zabawie, cel dzieła jest jak najbardziej serio). To, że balsam z drzewa działa w taki sposób jedynie na niego, również sytuuje go poza rzeczywistością. Autor celowo nie podejmuje żadnych wysiłków, by choć trochę uczynić go prawdopodobnym. Co nie oznacza, że jest niewiarygodny pod każdym względem.

Pora wrócić do ,śladów” pozostawianych przez bohatera w historii i przypomnieć dwa najwyraźniejsze i najlepiej oddające jego naturę i charakter działania - mowa oczywiście o nagrobku w Bolonii i kronice Nakorsa Warmisza. Autorstwo obu narrator przypisuje sobie, co więcej: objaśnia wszystkie związane z nimi tajemnice - znaczenie i historię:

[...] chcąc sytuacji mojej nadzwyczajnej zostawić potomności pamięć albo raczej aenigma, pod tytułem niby Aelii, matrony, sam sobie położyłem nadgrobek [...] Żeby więc uspokoić ciekawość mędrców, a razem do badania potrzebniejszych wiadomości nakłonić, tę życia mojego okoliczność umyślnie kładę [II, 3, s. 124-125].

W ten sposób pisze o nagrobku, krytykując jednocześnie pustą ciekawość, zwróconą w stronę tego, co nie przynosi pożytku.

Że zaś o wszystkich okolicznościach tak jak ja informowanym być nie mógł [Józef Andrzej Załuski - przyp. mój, K.L.], przeto niektóre błędy relacji jego poprawiam [...] Gdyby tę księgę kazali spalić wojewodo- 
wie, nie byłby ją mógł w słup zamurować Wojnar Walkoszyn grzebiąc za Gnieznem syna swego Zublina. Jam ją kazał zamurować dla przyczyny, którą niżej powiem [...] Data znalezienia roku 1574 prawdziwa [III, 6, s. 160-161].

Wyjaśnienia te dotyczą kroniki Nakorsa. Oba przywoływane ,ślady" zostawione w historii przez bohatera są, jak widać, falsyfikatami, a ten ich status podkreśla jeszcze fakt, że ich autorstwo przypisywane jest fałszywemu świadkowi dziejów. I odwrotnie, nieprawdziwość, zmyślenie, pozorna wartość przedmiotów charakteryzują swojego twórcę, pozwalają go rozpoznać jako byt równie niepewny jak one same. W ten sposób kompromitują się nawzajem, ośmieszając jednocześnie tych, którzy bezkrytycznie uwierzyli w ich prawdziwość i historyczną wartość.

Skoro próbujemy scharakteryzować postać narratora, wypada poruszyć jeszcze jedną kwestię. Zajmujący się Historia badacze tak charakteryzują Grumdryppa:

[...] to według założeń pisarza uosobienie oświeceniowego rozsądku i bezstronności. Nie należy do żadnej narodowości, z nikim nie wiąże się węzłami powinowactwa, nie piastuje wysokich godności [...] jego sympatie czy antypatie mają charakter filozoficznego stosunku do pewnych spraw człowieka stojącego ponad nimi. Jest nawet nieczuły na powaby płci pięknej [...] Wyposażył go Krasicki we wszelkie atrybuty, które mają warunkować postulowany przez Oświecenie obiektywizm krytyki historycznej ${ }^{6}$.

Nigdy też nie choruje. W swoich sądach jest beznamiętny i bezstronny?

Obie te opinie przypisują bohaterowi cechy nadludzkie, które zgadzałyby się niewątpliwie z jego wyjątkowym statusem - fikcyjnego uczestnika rzeczywistych wydarzeń, który nad „zwykłymi ludźmi” ma przewagę nieśmiertelności. Przewagę tę zawdzięcza zresztą tylko temu, że odkrył sposób na powracanie do młodości; gdyby został

6 M. Klimowicz, Wstęp [w:] I. Krasicki, Historia, PIW, Warszawa 1956, s. 13.

7 W. Walecki, op. cit., s. 117. 
w obrębie świata Swifta, nie byłby aż tak uprzywilejowany. Taki obraz, choć możliwy, nie jest jednak do końca zgodny z tym prezentowanym w tekście, wydaje się, że znakomici badacze tym razem dali się uwieść narratorowi i zobaczyli go takim, jakim chciałby być ${ }^{8}$. Przyjrzyjmy się jednak tym momentom, w których jawi się on nieupozowany.

Przede wszystkim Grumdrypp nie jest absolutnie obiektywny. Niewątpliwie jest tolerancyjny wobec różnych kultur, języków, zwyczajów, jednak jego ,zwykłe”, pierwsze życie musiało nań wpłynąć i go ukształtować. Stąd na przykład niechęć do wojennego rzemiosła, którą wyraża ironicznie:

Dano mi łuk, strzały, dzidę, jedną większą, drugą mniejszą; a żem się nie umiał z tą bronią obchodzić, setnik tak rzęsisto względem mnie używał kija, iż w kilka dni stałem się rycerzem ćwiczonym i w mojej profesji biegłym. W naszym kraju ten rodzaj nauki nie był używany, ale też nie było rycerzów [I, 2, s. 48];

a która w dużej mierze wynika z wychowania. Naturalną konsekwencją takiej postawy jest fakt, że ceni wyżej kraje nieekspansywne niż te, których polityka opiera się na podbojach, i przekłada władców rządnych nad ambitnych.

Jedynie dla Hannibala robi wyjątek. Nie krytykuje, jak by nie było, najazdu na Rzym, dopatrując się w tym konieczności politycznej. Nie zmienia to jednak faktu, że jako obiektywny i bezstronny obserwator powinien potępić i tę wojnę, zamiast pisać:

Nie należy dziwować się nad tym, iż szczęśliwe pierwiastki Annibala zły skutek wzięły; temu się bardziej dziwować należy, żeśmy mogli mieć

8 Wniosek, że Grumdrypp kreuje swój obraz, pozwala sobie autorka wyciągnąć na podstawie wielokrotnie podkreślanego przez narratora autorytetu, jakim powinien się cieszyć naoczny świadek wydarzeń, oraz wypominanych zasług, jakie już położył i możliwych, w dziedzinie literatury i nauki. Prawdopodobnie to właśnie przyczyniło się do wytworzenia takiej a nie innej wizji opowiadacza. Czytelnik nie powinien jednak mniemać, że bohater, opowiadając swoje dzieje, nie jest szczery, gdyby bowiem tak było, nie dałoby się odtworzyć jego rzeczywistego charakteru, sposobu myślenia i stosunku do oglądanej rzeczywistości. 
takowe pierwiastki z garstką niewielką wojska rozmaitych narodów, obyczajów, z małymi posiłki, w kraju nieznajomym, wśród ludzi nieprzyjaznych i zdradzieckich [I, 12, s. 73-74].

W podobnej sytuacji był nieraz Aleksander, ale jego podboje nie spotkały się z tak pozytywną oceną. Bierze się to z przekonania o wyższości Kartaginy nad Rzymem jako kraju kupieckiego, z sympatii do jej wodza jako dbałego o dobro państwa polityka, z niechęci do Rzymu wreszcie, do którego podmiot przekonuje się dopiero po pewnym czasie. A i tu wykazuje kolejne niekonsekwencje. Republika wydawała mu się odstręczająca przez swoją ekspansywność, jednak o czasach, gdy do władzy dochodził Cezar, pisze:

Im się bardziej na złe Rzymowi zanosiło [I, 20, s. 102]

i dalej o władzy Augusta:

Co lat dziesięć zdawał August jurysdykcją swoją w ręce ludu i senatu, jakby przy nich była najwyższa władza. Lud i senat wiedzieli, co ta grzeczność znaczy; i jakby nie dość było być niewolnikami, musieli jeszcze prosić o niewolą [I, 21, s. 105].

Niekonsekwencje te nie są, wbrew pozorom, przypadkowe. Spójrzmy na jeszcze jeden przykład ,uprzedzeńn” narratora:

[...] a gdy się skończyła, kazano mi klęknąć przed tym pudełkiem i tak jak drudzy dziewięć razy czołem o ziemię uderzyć. Czułem wstręt od tej podłości; postanowiwszy jednak dawniej u siebie żyć tak jak ci ludzie, w których bym się kraju znajdował, klęknąłem przed owym pudełkiem i uderzyłem dziewięć razy czołem o ziemię [II, 6, s. 138-139].

Grumdrypp ma po prostu na wiele rzeczy poglądy dobrze ukształtowane: brzydzi się przemocą, szczególnie taką, u której podstaw leży jedynie chciwość i ambicja. Wolność jest dla niego wartością zawsze i bez względu na okoliczności, dlatego w tak ostrym tonie wypowiadał się o postępkach Augusta, którego mimo wszystko uważał za do- 
brego władcę. Staje w obronie godności ludzkiej, jest przeciwnikiem władzy absolutnej. Kartagina jest dla niego wcieleniem ideału (czytelnik nie powinien myśleć tutaj o Kartaginie historycznej, lecz o wizji przedstawianej przez Krasickiego), dlatego wojna przez nią prowadzona ma dla niego charakter obrony tego, co wartościowe, i jako taka nie podlega potępieniu. Żeby móc udzielić nauki moralnej, trzeba najpierw określić jakiś system wartości, według którego rzeczywistość będzie oceniana. Kryterium korzyści, którym posługiwał się Książę Biskup w dwóch pozostałych powieściach, nie było wystarczające - wyprawy Aleksandra i władza Augusta przynosiły korzyść, a jednak nie zyskały aprobaty. Stąd właśnie pewna wizja świata, którą Grumdrypp ma w siebie ,wpisaną” i która uniemożliwia mu obiektywizm absolutny.

Zdarza się oczywiście tak, że bohater ,uczy się”, poznaje i dopiero wtedy ocenia. Wówczas kryterium jest zdrowy rozsądek, a głównym argumentem - rachunek zysków i strat:

Postanowiłem więc u siebie w rozmaitych naukach, a osobliwie w filozofii, wsparcia gruntowniejszego szukać [...] Zacząłem więc filozofować [...] uciekłszy z miasta odarty i bosy, w najpierwszym domku [...] zrzuciłem filozofskie gałgany przeklinając nie tak ludzi, którzy mnie znieważyli, jak profesją, która mnie i wstydu, i bólu nabawiła [I, 16, s. 85-87].

W ten sposób Grumdrypp poznaje i ocenia to, co nowe i z czym się wcześniej nie zetknął. Wówczas w istocie zdobywa się na obiektywizm, choć zaczyna od pewnego przekonania. W cytowanym fragmencie na przykład jest to przekonanie o wsparciu moralnym i wyższości, jakie daje filozofia. Trzeba zresztą przyznać, że z jednej skrajności nie popadł bohater w drugą i sprawdził różne kierunki filozoficzne, zanim zawyrokował o całości tej nauki. W podobny sposób wyzbywa się niektórych stereotypów:

Napisał późniejszymi czasy Tacyt o wyniesionych urzędem lub urodzeniem ludziach, iż się na dal lepiej wydają. Toż ja mniemałem o Amilkarze [I, 10, s. 68]. 
I znów bliższe poznanie Hannibalowego ojca pozwala sprawdzić zasadność tej opinii. Grumdryppem zresztą kieruje ciekawość i chęć poznania świata, dlatego nie trwa uparcie przy jednym przekonaniu. Jedynie pewne podstawowe wartości pozostają dla niego niezmienne.

Nie jest też narrator-bohater tak „nieludzki”, jak można by sądzić. Długowieczność bynajmniej nie pozbawiła go pewnych słabości, a wielość doświadczeń nie uczyniła zeń obojętnego i niepodlegającego emocjom. Zacznijmy jednak od wytknięcia bohaterowi jego słabostek. W pierwszym rzędzie kierowanie się uczuciami:

[...] że zaś nadto rozdrażniony byłem nieprawościami ludzkimi [...] zostałem cynikiem i w pierwszym zapale popędliwości mojej heroicznej wrzuciłem w morze resztę pieniędzy [I, 16, s. 86];

ponadto skłonność do nadużywania trunków:

[...] ja sam, upiwszy się wielokrotnie, dostałem febry kwartannej; byłbym może maligną przypłacił tej niewczesnej ochoty, gdybyśmy w domu dobrego lekarza nie mieli [I, 3, s. 53];

a nawet to, że zdarza mu się bać:

[...] ogień na kształt piorunu nagle wzniósł się ku górze [...] Zadrżałem patrząc na tak niespodziewane widowisko; wtem, gdy kilkadziesiąt podobnych piorunów razem się ku górze z trzaskiem wielkim wzniosło, odszedłszy prawie od siebie, począłem ze strachu krzyczeć i uciekać [II, 6, s. 139].

Oczywiście wszystkie te zarzuty należy traktować półserio, jednak nie są one bez znaczenia. Przede wszystkim dlatego, że wpisują się w polemikę z utopią nieśmiertelności. Możliwość wiecznego życia, która zdaje się być spełnieniem pragnień, w satyrycznym dziele Swifta staje się przekleństwem ze względu na utratę sił wraz z młodością. Grumdrypp zaradza temu za pomocą tajemniczego drzewka, więc wydawać by się mogło, że osiaga pełnię szczęścia, stan pożądany, który pozwala mu istnieć bez lęku przed śmiercią, gromadzić bogactwa i wiedze, cieszyć się urokami życia. Prawda jednak okazuje się inna. 
Zgromadzone doświadczenie nie uwalnia go od słabości ludzkich, na co dowodem są choćby powyższe przykłady, co więcej, jego niezwykły stan staje się przyczyną innych udręk. Początkowo są to obawy związane z możliwością utraty właściwości balsamu. W takim przypadku czeka go bowiem los gorszy od śmierci, której wcześniej bohater wręcz pragnął. Z czasem, gdy przestaje powątpiewać w trwałe działanie balsamu, okazuje się, że za nieśmiertelność płaci jeszcze inną cenę:

Jeżeli co zmniejszało szczęśliwość moją, było natenczas to, co najosobliwszym [...] uznawam przywilejem: moja nadzwyczajna trwałość. Myśl, że kochanych przyjaciół przeżyję, zaprawiała niekiedy goryczą dni moje słodkie [I, 14, s. 81];

te słowa objęte są jeszcze czarem „dni słodkich” i nadzieją, że moc balsamu pozwoli wydłużyć również życie przyjaciół. Jak na ironię po ich śmierci, po której żal stał się przyczyną decyzji o konieczności „odmłodnienia”, okazało się, że szczęście jest nietrwałe:

[...] jak najspieszniej oddalałem się od owego miasta, w którym niegdyś życie tak szczęśliwe wiodłem. Świeże doświadczenie dało mi uczuć, jak mało ubezpieczać się można na darach Fortuny, jak mniej jeszcze na ludziach [I, 16, s. 85].

Zresztą nie z każdą stratą tak łatwo przyszło mu się pogodzić:

[...] z niezmiernym żalem dowiedziałem się, iż syn mój w Tyrze, gdzie dla handlu był pojechał, po krótkiej chorobie życie zakończył. Uczułem tę stratę z niezmiernym umartwieniem [...] wziąłem z sobą znaczną sumę i puściłem się do Tyru [II, 5, s. 136].

Za każdym razem bohater decyduje się zacząć „,nowe” życie, wybór wyjazdu lub „odmłodnienia” jest namiastką śmierci, próbą ucieczki przed żalem po odejściu bliskich. A przecież nie są to wszystkie obawy, jakim podlega. Nieustannie musi ukrywać się ze swoją długowiecznością, sięgać po różne podstępy, pilnować słów, troszczyć się 
o swój balsam. Wreszcie samotność i wyobcowanie stają się jego udziałem, nie może być szczery nawet wobec przyjaciół:

Zdawało mi się podczas, iżem wykraczał przeciw obowiązkom przyjaźni, tając przed nimi sekret balsamu mojego; $z$ drugiej strony bałem się, aby takowe wyjawienie nie uczyniło w nich jakowej prewencji lub zazdrości, o co w ludzkiej naturze nietrudno [I, 14, s. 81].

Tak przedstawiona długowieczność, odarta ze swoich powabów, staje się głosem Księcia Biskupa w sprawie utopii nieśmiertelności, jest refleksją nad naturą człowieka i jego losem. Pesymistyczny wniosek, jaki z niej wypływa, jest jeszcze jednym dowodem na to, że prawdziwe szczęście daje umiar i pozostawanie w ramach wyznaczonych przez naturę9. Dla samej narracji zaś istotna jest ta „ludzka” kreacja narratora ze względu na pozycję, jaką zajmuje on wobec czytelnika. Zamiast być kolejnym mędrcem, którego opinie są niepodważalne, staje się kimś bliższym - uczestnikiem wydarzeń, którego słowa należy zważyć na szali rozsądku, ale w tonie którego nie ma nieznośnego pouczania; partnerem w rozważaniach dotyczących dziejów i człowieka. Zresztą taka kreacja postaci jest jak najbardziej zgodna z założeniem, jakie przyświecało Księciu Biskupowi przy tworzeniu dzieła. Grumdrypp pod pewnymi względami jest równie niewiarygodny jak inni kronikarze, a czytelnik ma za zadanie nauczyć się samodzielnie myśleć, szukać prawdy i wyciaggać wnioski.

\section{Odbiorca}

\section{Książę Biskup rzuca wyzwanie}

Kwestia adresu czytelniczego jest właśnie tym, co najbardziej wyróżnia Historię spośród powieści Krasickiego. Spróbujmy odtworzyć punkt widzenia czytelnika osiemnastowiecznego, gdyż jedynie w ten sposób można uchwycić wyjątkowość Historii i zrozumieć jej niewielką popularność wśród ówczesnych, tak chętnie sięgających po Mikoła-

\footnotetext{
9 Kwestię refleksji antropologicznej w Historii Krasickiego, tutaj jedynie zaznaczoną, pozostającą zaś do zbadania, zawdzięcza niniejsza praca p. prof. Teresie Kostkiewiczowej.
} 
ja Doświadczyńskiego czy Pana Podstolego. Dzisiejszy czytelnik, dla którego świat Mikołaja jest równie egzotyczny jak świat Grumdryppa i który przywykł do fantastyczności i gry między tekstami, nie odczuje tak wyraźnie tej różnicy, istotnej dla kreacji odbiorcy idealnego.

Przede wszystkim w przeciwieństwie do przywołanych powieści opisywana w Historii rzeczywistość dalece wykracza nie tylko poza ramy codziennego doświadczenia, lecz także niejednokrotnie poza zakres wiedzy o świecie „przeciętnego" ${ }^{10}$ odbiorcy. Podobnie jest z narratorem. Nie tylko nie pochodzi on z warstwy ziemiańskiej, lecz w ogóle jego genealogia jest obca, nieweryfikowalna, nie sposób zastosować wobec niego jakichkolwiek stereotypów, wymyka się klasyfikacjom. Jak by mało było tego, że pochodzi z przeszłości (epoki starożytne funkcjonowały wszak w powszechnej świadomości jako źródło wzorców i archetypów, nie były więc czytelnikowi ziemiańskiemu całkowicie obce), jego korzenie są fantastyczne, baśniowe. Następuje więc podwójna dezorientacja - zarówno co do przedstawionego świata, jak i bohatera, który o nim opowiada, a z którym nie sposób się utożsamić, który jest obcy.

Pozostaje jeszcze pytanie, dlaczego ta inność narratora jest tak istotna. Przede wszystkim dlatego, że stawia przed sięgającymi po powieść nowe wymagania. Opowiadacz nie jest medium pomagającym swojemu interlokutorowi odnaleźć się i zakorzenić w świecie przedstawionym, ale staje się partnerem zapraszającym do wspóluczestnictwa i gry ${ }^{11}$. Zamiast wyznacznika społecznego kryterium decydującym o porozumieniu między autorem a czytelnikiem stają się erudycja i wiedza ogólna ${ }^{12}$. Przyjrzyjmy się teraz, jakie zadania stają przed tymi, którzy to zaproszenie przyjmą.

10 Autorka zdaje sobie sprawę z niestosowności terminu ,przeciętny odbiorca”, z braku jednak innego określenia na czytelnika pochodzącego z warstwy ziemiańskiej, kształconego w szkołach publicznych lub w domu, o zakresie zainteresowań obejmujących przede wszystkim sprawy życia codziennego - słowem typowego reprezentanta średniozamożnej szlachty, a tacy właśnie byli adresaci pierwszych powieści Krasickiego, zmuszona jest go stosować.

${ }^{11}$ O Historii w kategoriach gry pisał W. Walecki (por. W. Walecki, op. cit.).

12 Chciałoby się to ująć w kategorii fortunnego i niefortunnego komunikatu, z tym, że dotyczy to raczej aktu odbioru niż nadania. To właśnie niefortunny odbiór wpłynął na małe zainteresowanie Historiq u ówczesnych i w konsekwencji również współczesnych. Trzeba zresztą przyznać, że Książę Biskup przed swoim czytelnikiem stawia wysokie wymagania. 
Wirtualny odbiorca jest przede wszystkim znakomicie obeznany z historią starożytną oraz początkami państwa polskiego i zna dotyczące ich źródła tak dobrze, by opowiadacz mógł, nie tracąc czasu na zbędne thumaczenia, komentować pewne zaistniałe w niej fakty lub opowiadać anegdoty, na przykład:

Córka jego Wenda, albo Wanda, nie wzgardziła Rytygierem, bo go na świecie nie było. Nie skoczyła z mostu w Wisłę, bo pod Krakowem na łodziach się przewożono; że utonęła, to prawda, ale nie ona była temu winna, lecz przewoźnik pijany [III, 6, s. 157].

Polemika z legendą Wandy przeprowadzona jest tak, że niezorientowany w legendach polskich odbiorca nie odczuje jej ostrości. Narrator jednak nie wprowadza go w podstawy, nawet o nich nie wspomina, zakłada, że są mu świetnie znane. Opinia pochlebna, o ile czytelnik stanie na wysokości zadania. Jeśli nie - zamysły autora, jego wizja nie tyle dziejów, ile ludzi dawnych i współczesnych, pozostaną przed nim ukryte, ironia i żart - niezrozumiane.

Zdarza się jednak, szczególnie w przypadku polemik z kronikarzami starożytności, że narrator jako rzekomy autor dzieła (którą to funkcję przypisuje mu Przedmowa i która zostaje konsekwentnie podtrzymana przez kształt przypisów), dbając o ścisłość i prawdę, opierając się na źródłach, jak przystało w dziele mającym ambicje rewizjonistyczne $^{13}$, robi odnośnik do tekstu i w przypisie cytuje dosłownie fragment dzieła, z którym wchodzi w dyskusję:

„In ulteriori cuius ripa [Hydaspis] Porus consederat, transitu prohibiturus hostem LXXXV elephantos obiecerat, eximo corporum, robore, ultaque eos currus CCC et peditum XXX fere milia” [p, I, 2, s. 49].

Fakt, że podaje je w oryginalnym łacińskim brzmieniu, nie powinien dziwić czytelnika, który znał poglądy Księcia Biskupa ${ }^{14}$. Cyto-

\footnotetext{
13 Trzeba tu jednak rozróżnić pomiędzy intencją autora a Autora, czyli Grumdryppa, który jako świadek naoczny dąży do przedstawienia prawdy historycznej i weryfikacji dotychczasowych opinii o dawnych wiekach, i Krasickiego, któremu naprawdę nie o liczbę słoni idzie.

14 W Panu Podstolim są one wyrażone expresis verbis: „Gdyby za wspólną narodów zgodą jeden był język wybrany do nauk, wzniosłyby się w dwójnasób. Do żadnego się w szczególno-
} 
wanie dawnych pism w ich oryginalnym brzmieniu wyraża implicite zapatrywania rzeczywistego autora na to, czym jest i na czym opiera się kultura, i wyznacza krag ,wtajemniczonych”, zawęża adres czytelniczy, mimo że w tekście powieści tłumaczy on, parafrazując, opinie kronikarzy, z którymi w polemikę wchodzi. Znajomość dziejów, przynależność do grona ludzi, dla których łacina jest językiem ,żywym”, którzy biegle się nią posługują - to dwa warunki, które stawia przed czytelnikiem Historia.

Skoro zaś jesteśmy przy przypisach „odautorskich”, wypadałoby bliżej przyjrzeć się, w jaki sposób służą one nawiązywaniu kontaktu z odbiorcą. Nie tylko bowiem stanowią potwierdzenie słów opowiadacza poprzez przytoczenie cytatu ze starożytnego autora, lecz także są miejscem na komentarz bezpośrednio się do nich odnoszący. Taki zabieg nie powtarza się zbyt często, tym bardziej jednak warto zwrócić na niego uwagę. Przykładem może być komentarz dotyczący Seneki [p, II, 1, s. 119], który ma na celu potwierdzenie prawdy słów Grumdryppa przez przywołanie innych, podobnie sądzących, a istniejących rzeczywiście, pisarzy. Interesujący jest jednak również dalszy ciąg:

Qua sapientia, quibus philosophorum praeceptis, intra quadriennium regiae amicitiae ter millies sestertium paravisset (Ter milies sestertium wynosi złotych polskich pięćdziesiąt dziewięć milionów trzykroć siedemdziesiąt i pięć tysięcy.) [p, II, 1, s. 119];

przede wszystkim dlatego, że przeliczenie na walutę polską jest wskazówką dotyczącą tego, do kogo Historia jest adresowana. Abstrahując od miejsca rzekomego znalezienia rękopisu, które mogło być przypadkowe, i języka, w którym był napisany, jest to najwyraźniejsza i odautorska wskazówka określająca odbiorcę. Ponadnarodowe i ponadczasowe treści zawarte w dziele Krasickiego stanowią kolejny krok na drodze przemiany sposobu myślenia, już nie szerokich rzesz szlacheckich, lecz ludzi światłych - obywateli Rzeczpospolitej.

ści nie przywiązuję, ale by się godziło przywrócić łaciński do dawnej posesji. Teraz, słyszę, zaczyna powszechnieć; tym gorzej" [I, 1, 5, s. 19]. Cyt. za: J. Krasicki, Pan Podstoli, red. K. Stasiewicz, Olsztyn 1994. 
Następny przypis ma nieco inną funkcję niż wcześniej wymieniony, dlatego przyjrzyjmy się i jego treści:

Korespondencja Aleksandra z Arystotelesem w tymże Kadłubku wyrażona bardzo ciekawa. Z niej się dowiedzieć można, jako stołeczne Lechitów miasto nazywało się Caranthas; jako Aleksander do nich takowy list pisał: „Si sapitis? valebitis; sin autem, non.” Jako tych listów było więcej niż dwieście. - Żal się Boże, że zginę̨y! [p, III, 6, s. 158].

Tym razem posługuje się narrator ironią i to ostrą, zapowiadają ją już słowa: „w tymże Kadłubku”, które tworzą dystans intelektualny pomiędzy opowiadającym a kronikarzem polskim, i elipsa: „korespondencja [...] w tymże Kadłubku wyrażona bardzo ciekawa”. Wykrzyknienie na końcu - niezwykłe u dość opanowanego narratora - potęguje ten efekt, przez zwrot do Najwyższej Instancji nadając zaginięciu rzekomych listów rozmiary straszliwej katastrofy. Warto jeszcze zwrócić uwagę na kształt paralelnych zdań, które streszczają zawartość zaginionej korespondencji. Przypominają budową inną zmyśloną historię z innej powieści:

[...] jako Julianna zamknięta w klasztorze, ciężko płakała straty amanta swojego; jako jednego czasu przechodząc się z towarzyszkami po ogrodzie porwana była gwałtownie przez nieznajome osoby; jako w oddalonej puszczy odbita znowu była przez drugie nieznajome osoby [III, 17, s. 265] $]^{15}$.

Wydaje się, że taką budową również chciał mniemany autor rękopisu wyrazić powątpiewanie w prawdziwość listów i zawartych w nich informacji. Skąd jednak tak ostra krytyka? Być może stąd, że mógł być Książę Biskup wyrozumiały dla tworzenia w dziejach własnych wzorców osobowych zaczerpniętych z legendarnych dziejów innego narodu, ale raził go brak umiaru nawet w nobilitowaniu własnego kraju i niepokoiły jego konsekwencje.

Kolejną właściwością czytelnika wirtualnego, jak już wspominaliśmy, jest erudycja. Idealny odbiorca powinien przywoływane dzie-

15 I. Krasicki, Mikołaja Doświadczyńskiego przypadki, [w:] Idem, Działa wybrane, t. 2, oprac. Z. Goliński, PIW, Warszawa 1989. 
ła starożytnych znać i bez przypisów. Również dzieła współczesne nie powinny być mu obce, jeśli chciałby odszyfrować wszystkie znaczenia zawarte w powieści. Wspominaliśmy już o dosłownym cytacie ze Swifta, a przecież wspomina Grumdrypp również ody Pindara, pieśni Horacego, treny Owidiusza i inne dzieła od starożytności poczynając, a na Telemaku - jako tekście porównawczym dla opisu Hiszpanii i wymienianym już Programma literarium - kończąc. Odbiorca-erudyta dostrzeże też zaczerpnięty z Robinsona Crusoe motyw samowystarczalnego życia [II, 10], przedstawiony jednak inaczej, w świetle dobrowolnego powrotu do natury z pism Rousseau. To, co dla angielskiego rozbitka było wyzwaniem i walką o przetrwanie, dla narratora Historii jest sposobem na szczęśliwe życie, z dala od niegodziwości świata, ludzkich podstępów i strachu (na marginesie, jakże różna jest ta postawa od prezentowanej przez Grumdryppa na samym początku [I, 2], kiedy to powrót do życia wśród ludzi stał się spełnieniem jego pragnień).

\section{W świecie tekstów}

Zastanawiając się nad relacjami Historii z innymi tekstami literackimi, czy ściślej rzecz ujmując - z innymi powieściami, można zauważyć pewne podobieństwo do jeszcze jednego dzieła. Mowa o Tristramie Shandym Sterne'a ${ }^{16}$. Podobieństwo to zasadza się przede wszystkim na sposobie ukształtowania narracji - nieodmiennie angażującej i zaskakującej czytelnika, na wszystkich zabiegach, jakie podejmuje opowiadacz, żeby wejść z nim w kontakt, żeby zmusić go do aktywności i współuczestniczenia. Różnica jest ta, że u Sterne’a porozumienie z odbiorcą przebiega na płaszczyźnie kompozycji i dotyczy powstawania tekstu, możliwości kreacyjnych autora, sposobów przedstawiania świata. Krasicki natomiast nawiązuje dialog na poziomie idei, sposobów rozumienia, przedstawiania i oceniania człowie-

\footnotetext{
${ }_{16}$ Krasicki miał w swojej bibliotece sześciotomowe wydanie Oeuvres de Sterne traduites de l'anglais wydane w Paryżu w 1797 roku. Nie wiadomo jednak czy znał wcześniej Życie i myśli Jaśnie Wielmożnego Pana Tristrama Shandy, czy też ten sposób gry z czytelnikiem jest jego własnym pomysłem. [Podaję za: Inwentarz biblioteki Ignacego Krasickiego z 1810 roku, oprac. S. Graciotti, J. Rudnicka, Zakład Narodowy im. Ossolińskich, Wydawnictwo PAN, Wrocław 1973.].
} 
ka i jego świata. Do tego zaś, by dialog był możliwy, niezbędny jest wspólny zakres wiedzy i doświadczeń, wspólny język kulturowy. Dlatego Historia stawia swojemu czytelnikowi tak wiele wymagań.

Erudycja idealnego odbiorcy pozwala mu nie tylko bezbłędnie rozszyfrowywać aluzje, rozpoznawać źródła interstekstualnych odwołań i pozostawać w nieustannym porozumieniu z narratorem, utrzymywać jego zawrotne tempo prezentowania świata, kultury, sztuki w coraz to nowych odsłonach, lecz także zorientować się w czymś, co można by nazwać literacką mapa, na której Historia jest usytuowana. Mówiliśmy już o Swifcie i o tym, w jaki sposób narrator podejmuje jego grę, traktując Podróże Guliwera tak, jak wynikać by mogło z poprzedzającego je listu, czyli jako rzeczywisty dokument, i jak uwierzytelnia swoje istnienie zapiskami Guliwera. A także o tym, jak rzeczywisty autor powieści podejmuje i prowadzi dalej refleksję nad nieśmiertelnością człowieka. Jednak to nie wszystko, bowiem powieść, w duchu sternowskim, zaplątana jest $\mathrm{w}$ jeszcze inne relacje międzytekstowe, czyli w przestrzeń twórczości samego Księcia Biskupa. I tu właśnie jest miejsce dla tworzenia i rozbijania iluzji i literackości, dla demistyfikacji i przybierania masek. W Podróży z Warszawy - jednym z wierszy z prozą - zwierza się Książę Biskup swoim czytelnikom:

Zatrzymała mnie jednak ciekawość przy owej karczmie, gdzie jak powiadają, między Biłgorajem a Tarnogrodem Kozak jakowąs starą księgę znalazł.

Pytałem gospodarza, skąd wieść poszła taka?

Rzekł z przysięgą: „I ksiegi nie znam, i Kozaka.”

Chciałem więc reszty szukać, a gdym Żyda sfukał,

Znalazłem, ale wcale nie tę, którąm szukał ${ }^{17}$.

W ten sposób jednocześnie zaprzecza istnieniu rękopisu i wszystkim zabiegom, zastosowanym w Przedmowie, które miały go uwiarygodnić, oraz odcina się od bycia jego autorem. Przybiera maskę na-

17 I. Krasicki, Podróż z Warszawy. Do księcia Stanisława Poniatowskiego [w:] Idem, Pisma wybrane, t. 2, oprac. Z. Goliński, M. Klimowicz, R. Wołoszyński, red. T. Mikulski, PIW, Warszawa 1954, s.181-182. 
wet nie tyle czytelnika, ile kogoś, kto zaledwie słyszał o „sławnym” rękopisie i jest nim zainteresowany jako lokalną osobliwością. Zresztą w ten sposób „odpłaca się” edytorowi manuskryptu, który w przypisie do dzieła Grumdryppa tak źle go potraktował, określając mianem „jakiegoś poety” i zarzucając fałsz. Autoironia Krasickiego, którego poglądy na wierność historycznej prawdzie i zadania stawiane przed historią jako nauką znaleźć można już w liście Do Ks. Adama Naruszewicza, Koadiutora Smoleńskiego, sięga niezwykle daleko, kiedy sam stawia siebie w rzędzie niewiarygodnych kronikarzy, z którymi przez całą powieść polemizuje. Zresztą nie jest to jedyny autoironiczny komentarz ${ }^{18}$. Jest zatem w powieści Księcia Biskupa miejsce i na rzeczywistość, i na literaturę, i na grę między nimi.

\section{Konstrukcja}

\section{Podstawa}

Pora przyjrzeć się temu, w jaki sposób tworzona jest fabuła powieści i jak prezentowany jest świat przedstawiony. W Historii wyróżnić możemy dwa poziomy akcji: pierwszy to poziom bohatera i jego „historii prywatnej", czyli te wszystkie momenty, w których Grumdrypp swoje opowiadanie skupia na sobie jako jednostce:

Codziennie dwa razy przychodził do mnie ten nauczyciel i w kilka niedziel już mogłem rozumieć gadających, z czasem sam mówić dość dobrze nauczyłem się. Po czterech miesiącach nauki zaprowadzono mnie do rządcy [I, 2, s. 47].

Dystans narratora do prezentowanych wydarzeń określić możemy jako pamiętnikarski - relacjonowane są dłuższe okresy czasu (,,w kilka niedziel”, „po czterech miesiącach”), pojawia się wyraźna podsumowująca tendencja (,zz czasem sam mówić dość dobrze nauczyłem się"), choć zdarza się, że ulega on skróceniu:

18 Inny, dotyczący zawodu pisarza, znajduje się w trzeciej części [III, 9, s. 167]. 
Czułem po przebudzeniu jakowąś odmianę i wewnętrzną rewolucją i ledwom sobie mógł wierzyć, gdy, przedtem nie mogąc się prawie ruszyć bez pomocy laski, porwałem się rześko i stanąłem na nogach [I, 1, s. 45].

Wówczas uwaga narratora koncentruje się na wydarzeniach, które mają miejsce w krótkim przeciagu czasu, przywołuje je kolejno, zwraca uwagę na swoje emocje. Takie sytuacje są jednak dość rzadkie i wiążą się albo z przełomowymi momentami w życiu bohatera (jak powyższy lub moment ucieczki z więzienia [I, 16]), albo mają cel dydaktyczny, a przykładem jest sam opowiadacz właśnie (postawa Grumdryppa po stracie majątku na schodach świątyni [I, 7] lub pokaz sztucznych ogni w Chinach [II, 6]).

Drugi poziom to poziom historii, dziejów ludzkich, w których bohater jest tylko częścią zbiorowości:

Następca tronu, tejże co i przeszły dynastii, nazywał się Lin-ti, jeszcze gorszy, a bardziej nikczemniejszy od przeszłego. Ten, lubo mnie do dworu nie kazał wzywać, wszystko mnie jednak dochodziło punktualnie. [...] Na koniec Tong-tcho, wódz najwyższy bunt podniósł [...] W tym zamieszaniu straciłem wszystko [II, 9, s. 146].

Konkretne wydarzenia historyczne - zmiany cesarzy, bunty - mają swoje konsekwencje w życiu narratora, jednak to na przebieg dziejów społeczeństwa, a nie na jego losy zwrócona jest uwaga. Dystans jest wówczas jeszcze większy, można go określić jako kronikarski, opowiadacz odnotowuje bowiem najważniejsze fakty z historii ogólnej, czasami zaznaczając swoje w nich uczestnictwo. Uczestnictwo to zresztą, jak zauważył Walecki ${ }^{19}$, jest przede wszystkim bierne.

W ten sposób przedstawiona jest fabuła, pora przyjrzeć się światu przedstawionemu. Najistotniejszym wyznacznikiem są opisy, a raczej ich kształt. W całym dziele zdarzają się dość rzadko i daleko im nie tylko do zmysłowych i szczegółowych obrazów z Pana Podstolego, lecz nawet do krótkich i wydobywających najważniejsze właściwości

19 Zob. W. Walecki, op. cit., s. 97. 
przedstawień z Mikołaja Doświadczyńskiego. Celem większości opisów jest raczej scharakteryzowanie niż unaocznienie przestrzeni:

Tuż za miastem miałem piękną winnicę i przy niej domek gustowny, ale niewielki [...] Przy pałacu miejskim założyłem ogród piękny i bardzo obszerny [I, 14, s. 79].

Najczęściej używany przymiotnik - ,piękny” - nie służy prezentacji, a ocenie. Wymienione elementy przestrzeni zdają się być dekoracją teatralną: domek - gustowny, niewielki; ogród - obszerny, piękny; winnica - piękna i tak dalej. Wszystkie one wraz z określającymi je przydawkami mają oznaczać dostatek, ład i gust, nie zaś ewokować wyglądy. Można traktować je jako umowne znaki: bohater żyje szczęśliwie i w umiarze, panuje epoka spokoju. Opis taki staje się przez to również charakterystyką szerszego kontekstu, w którym zawsze umieszczony jest Grumdrypp: Efez, w którym przebywa, jest miastem bogatym, nie jest uwikłany w żadne wojny, cieszy się pokojem, dzięki któremu może się rozwijać, z czego korzystają również obywatele. Tym samym jest przeciwieństwem wszystkich uwikłanych w konflikty zbrojne miejsc. A wniosek, który może z tego wyciągnąć czytelnik? Nie wojowanie czyni narody szczęśliwymi. Nie jest to bynajmniej za daleko posunięta interpretacja $\mathrm{i}$ - biorąc pod uwagę cel dzieła i sposób, w jaki Książę Biskup rozumiał historię - pokrywa się z intencją autora. Powróćmy jednak do opisów. Najbardziej ,żywy” i oddziałujący na wyobraźnię jest najwcześniejszy z nich - prezentacja miejsca, w którym doszło do pierwszej przemiany bohatera:

[...] gdzie między skałami piękną dolinę dzielił bystry, po kamykach spadający strumyk. Cień cedrów stoletnich uśmierzał upały słoneczne, a w pobliskiej skale jakby kunsztem ręki ludzkiej sporządzone pieczary stały mi się miejscem wygodnym dla spoczynku [I, 1, s. 45];

i dla porównania opis miasta: 
Miasto było dość ozdobne, porządne i ludne. Domy inakszym, prawda, kształtem budowane niżeli u nas, przystojne jednak i wygodne [I, 2, s. 47].

Mamy tu do czynienia z intelektualnym, a nie zmysłowym oglądem świata, skłonnością do wyciagania wniosków z doznawanych wrażeń - miasto ozdobne, porządne i ludne można by przecież przedstawić za pomocą opisu architektury, tłumu na ulicach, poszczególnych, zwracających uwagę elementów.

Na szczególną uwagę spośród opisów przestrzeni zasługująjeszcze opisy „,chińskie”, przede wszystkim dlatego, że jest ich niespodziewanie dużo i dotyczą nie tylko miejsc, lecz także znajdujących się w nich ludzi i przedmiotów:

Był to starzec poważny, ubrany w długie suknie z rękawami do samej ziemi. Materia sukien była jedwabna, fiałkowa w kwiaty; na piersiach miał jak tablicę, na której był smok haftowany, bez pazurów, ta bowiem dystynkcja samemu cesarzowi służy [II, 7, s. 141].

W powyższym fragmencie szczególną uwagę należy zwrócić na zakończenie: „ta bowiem dystynkcja samemu cesarzowi służy”. Zawiera ono informację dotyczącą kultury Chin, która dla Europejczyka zawsze będzie obca i odmienna. Można nawet posunąc się do przypuszczenia, że podobne opisy pojawiają się dlatego, by, jak twierdził Klimowicz we wstępie ${ }^{20}$, oddać egzotykę tego kraju, a zamieszczone na końcu uwagi służą nie tylko pouczeniu czytelnika o nieznanym mu świecie, lecz także zaznaczeniu tej egzotyczności właśnie. Byłoby to zatem jedynie poszerzenie o nowe elementy wobec wcześniejszych opisów i tak jak one, opisy „chińskie” oznaczałyby, zamiast wywoływać wrażenie, byłyby rodzajem teatralnej dekoracji.

Kolejnym rodzajem prezentacji, czy raczej w przypadku Historii - charakterystyki przestrzeni, są dwa fragmenty poświęcone przedstawieniu dwóch krajów. Nieprzypadkowo jednym z nich są dopiero co omówione Chiny [II, 8, s. 145], zaś drugim - Hiszpania [I, 9, s.

$20 \quad$ M. Klimowicz, op. cit., s. 22, passim. 
66-67]. Wykraczają one poza ramy obrazowości, przypominają raczej relacje podróżników i, tak jak opowieść Mikołaja o Nipu, zorientowane są wokół najważniejszych zagadnień z zakresu kultury, historii i obyczaju. Nie można mówić o jakichkolwiek próbach unaocznienia. Opis Chin to wyłącznie opis cech umysłowości - sposobu myślenia o dziejach, nauce, postępowaniu. Na marginesie warto zauważyć, jak zręcznie i taktownie postąpił Książę Biskup, krytykując wprost w kronikarzach chińskich to, co zarzucał również europejskim - skłonność do zmyśleń i legend nobilitujących własny naród poprzez mityczne początki. Czytelnik w żaden sposób nie może czuć się dotknięty, a naukę zapamięta. Opis Hiszpanii sięga jeszcze dalej, ponieważ przestaje być nawet podróżniczą relacją, a staje się obrazem idealnych stosunków, utopią. Znów zatem odnosi czytelnika poza próbę konkretyzacji przestrzeni akcji do abstraktów, znaków i symboli kultury, do dziedzictwa myśli.

Zastanawiając się nad podstawą konstrukcyjną powieści, wypada jeszcze zwrócić uwagę na jej wewnętrzny podział. Granica między pierwszą a drugą częścią przebiega w toku lektury niemal niezauważalnie. Nie zmienia się zasadniczo ani czas, ani przestrzeń, w których toczą się wydarzenia. Fabularna ciagłość jest zachowana, właściwie wydawać by się mogło, że podział jest całkowicie przypadkowy. Inaczej dzieje się w przypadku granicy między księga drugą a trzecią, która poprzedzona jest notką skrupulatnego wydawcy:

Tu kilkadziesiąt kart z manuskryptu świeżo było wydartych, mimo najusilniejsze moje starania znaleźć ich nie mogłem. Co więc na pierwszej karcie po wydartych następowało, wiernie kładę [II, 10, s. 151].

Tym razem cele autorskie są jasne, ów brak spowodowany jest chęcią oszczędzenia sobie i czytelnikowi niecierpliwego oczekiwania na naprawdę zajmującą go kwestię, czyli początki narodu polskiego. Wydawca okazuje się więc użyteczny, z powodzeniem zewnętrznymi przyczynami usprawiedliwiając ogromny przeskok czasowy i przestrzenny, jaki dokonuje się między księgami drugą i trzecią. Trzeba jednak oddać sprawiedliwość dbałości Księcia Biskupa o szczegó- 
ły. Mimo początkowej dezorientacji czytelnik szybko odnajduje się w nowych zagadnieniach, a jego przekonanie, że ma do czynienia $\mathrm{z}$ jednym, choć nieco wybrakowanym tekstem, podtrzymywane jest przez ukształtowanie narracji w taki sposób, jakby miał do dyspozycji całość:

Wyżej namieniłem, skąd Lech przyszedł, jakie były przyczyny i okoliczności przyjścia jego, jaka familia, z której pochodził. Zostaje mi teraz wyrazić, co czynił, osiadłszy w kraju wynalezionym [III, 6, s. 154].

Oczywiście odbiorca tekstu nie ma pojęcia, skąd Lech przyszedł, jakie były przyczyny i okoliczności przyjścia jego i z jakiej wywodził się rodziny. Rękopis jednak zachowuje ciagłość. Jest ona raz jeszcze podkreślona przez kolejną wzmiankę narratora:

Jakim sposobem dostałem się w towarzystwo Lecha, wyżej namieniłem [III, 6, s. 158],

a gdy najważniejsze kwestie polemiczne (bo księga trzecia, szczególnie fragmenty dotyczące Polski, opiera się niemal wyłącznie na polemice z dotychczasowymi dziełami kronikarskimi) zostaną wyczerpane, wydawca znów wykazuje swoją użyteczność, lakonicznie kończąc całe dzieło słowami:

Reszty nie masz [III, 10, s. 169].

Z powyższych rozważań wynika podstawowy dla „fortunnego" odbioru wniosek - celem narratora, a zatem i rzeczywistego autora powieści nie jest prezentacja świata przedstawionego (można tak przypuszczać, biorąc pod uwagę ubóstwo środków) ani losów bohatera (skoro uwaga opowiadacza nie skupia się ani na jego życiu wewnętrznym, ani na jego jednostkowych losach). Żeby móc odkryć, co w takim razie jest celem Grumdryppa i Krasickiego, przeanalizujemy inne środki podawcze i sposoby urozmaicania fabuły. 


\section{2. „Dygresje”}

Skoro nie fabuła, jak w Doświadczyńskim, ani świat przedstawiony, jak w Panu Podstolim, co zatem jest nośnikiem najważniejszych sensów Historii? Badając tę powieść, dostrzegamy, że ma ona budowę ,dygresyjną", akcja właściwa jest co i raz przerywana przez różne narratorskie zabiegi, które wypływają z relacjonowanych zdarzeń, jednocześnie poszerzając krąg wiedzy, otwierając dla wydarzeń nowe konteksty. Sposobem przekazywania tych treści są różne środki podawcze.

Jako pierwszy i, co zaskakujące, najmniej nośny, najrzadziej stosowany, wymienimy refleksje. Różnice między nimi zasadzają się przede wszystkim na ukształtowaniu i pochodzeniu. Znajdują się wśród nich takie, które otwiera bezpośredni zwrot do czytelnika, lecz przeważają inne, zaczynające się ,bez ostrzeżenia” od zdania oznajmującego i tylko ich uogólniający charakter pozwala zorientować się, że nie są częścią relacji:

Wiadomi trybu wojennego nie na samych bitwach wygranych zasadzają umiejętność wodzów; [...] rozporządzenie całej kampanii, opatrzenie wojska w dostateczną żywność, marsze wczesne, pozycje dobrze obrane [...] to wodzów zaszczyca [I, 12, s. 74].

Zresztą zawsze ich zakończenie otwarte jest na dalszy ciąg snutej przez narratora historii, odnosi się w bezpośredni sposób do zdarzeń lub bohaterów:

[...] i w tym właśnie celował innych Hannibal tak dalece, iż gdy w rozmowie z Scypionem jego nad siebie przeniósł, bardziej to było skutkiem modestii lub polityki niźli prawdą rzeczywistą [I, 12, s. 74].

Różne są także źródła, z których wypływają refleksje opowiadacza. Większość z nich odnosi się do rzeczywistości pozaliterackiej i czerpie $\mathrm{z}$ dokonanych w niej spostrzeżeń autora. Za przykład może posłużyć już cytowany fragment, w którym poruszane zagadnienia dotyczą 
sztuki prowadzenia wojen, być może jednak bardziej reprezentatywny będzie następujący cytat:

Nad tym się zastanawiać zwykli prawi kronikarze, ażeby, opisawszy dzieje zacnych ludzi, ich charakteru, sposobu działania i myślenia określili wyobrażenie. Tym sposobem oświecony, czytelnik poznaje doskonale tę osobę, której dzieje czyta, wchodzi w najskrytsze onej wzruszenia, a, jąwszy się tego pasma, docieka łatwie, jakie być mogły pobudki czynności, nad którymi się zastanowił. Historia tym sposobem uważana nauką jest obyczajów [I, 4, s. 54].

Jest to opinia autorska, którą nota bene dzielił Książę Biskup z wieloma znakomitymi umysłami oświecenia, znana czytelnikowi z innych jego dzieł. Narrator nie wygłasza jej w oparciu o swoje dotychczasowe doświadczenia, lecz podaje ją jako aprioryczne założenie, podstawę swojej działalności i bodziec do podjęcia relacji o swoim życiu. To zwrócenie „na zewnątrz” cechuje zresztą całą zawartość myślową Historii - świat przedstawiony składa się z samych konturów, fabuła toczy się dzięki motywacji będącej w najlepszym razie naukową fikcją (w najgorszym - baśnią), a wszystkie przedstawione w niej sądy i wnioski wykraczają poza komizm czy grę i powinny być traktowane jak najbardziej serio. Odnoszą się one bowiem do rzeczywistości pozaliterackiej nie poprzez pośrednictwo świata przedstawionego i jego podobieństwo do świata prawdziwego, lecz bezpośrednio. Można powiedzieć, że w niej biorą swój początek i w niej jest ich cel, a zmyślona, fantastyczna opowieść jest jedynie medium. I wydaje się, że to właśnie jej nierealność jest gwarantem tego, że odbiorca doszukiwał się w niej będzie czegoś więcej. Jego celem nie jest poprzestawanie na zewnętrznej szacie, lecz dążenie do ledwo nią przesłoniętego przekazu, do właściwej treści. Nie ma tu mowy o żadnym utożsamianiu się czy choćby przejęciu zmyśloną fabułą. Różne zabiegi demistyfikacyjne, jakimi posłużył się Książę Biskup, miały upewnić jego partnera w grze, że jest ona nieistotna. Analogicznie jak w przypadku bajek - istotna treść spoczywa pod zmyśleniem. 
Powróćmy jednak do drugiego rodzaju refleksji, których źródłem jest dotychczasowe istnienie narratora, czyli które są umotywowane zdarzeniami w świecie przedstawionym:

Stan kupca jest dość szczęśliwy, ale, według mojego zdania, nie może się równać z rolnictwem. Ustawiczny przemysł imaginacją natęża, bojaźń straty czyni niespokojnym. Ilem razy wysyłał okręty na morze, lubom się przeciw nieprzewidzianym wypadkom ile możności uzbrajał, przecież trwożliwość moja przezwyciężała uwagę [II, 3, s. 127-128].

Zacytowany przykład, podobnie jak pozostałe, jest wynikiem rozmyślań związanych z bieżącą sytuacją narratora-bohatera (bieżąca znaczy w tym przypadku akurat omawiana, dystans bowiem pozostaje niemal wyłącznie pamiętnikarsko-kronikarski) i ma poparcie w przedstawionych $w$ fabule wydarzeniach i opowiedzianej już historii.

Innym sposobem przerywania fabuły w celu poszerzenia świata przedstawionego, czy może raczej w przypadku tego dzieła - świata przemyślanego, gdyż w jego obrębie najważniejsze są wyabstrahowane ze zdarzeń wnioski, jest charakterystyka bohaterów. W przeciwieństwie do bohaterów pozostałych powieści Krasickiego (Historia najlepiej ,wydaje się" na tle swoich poprzedniczek) nie są to charakterystyki powierzchowne ani krótkie, przeciwnie, dotyczą one wyłącznie cech wewnętrznych (naprawdę rzadko zaznaczone jest istnienie tego, co powierzchowne) i zmierzają do wyczerpującego, przekonującego i całościowego przedstawienia postaci ${ }^{21}$. Jest to zresztą zgodne $\mathrm{z}$ dopiero co cytowanym poglądem opowiadacza na historię jako naukę o dziejach. Postacie, które prezentuje Grumdrypp, podzielić można wedle dwojakich kryteriów: albo na rzeczywiste i fikcyjne, albo na pozytywne, ambiwalentne i negatywne. Przy czym dokładnie przedstawione charaktery fikcyjne zawsze pełnią rolę wzorcową. Są to zresztą jedynie dwie charakterystyki - kupca Hannona i Leontiusa. Pierwszy z nich określany jest przede wszystkim przez swoje postępki:

21 Wacław Walecki w cytowanej już książce zauważył, że charakterystyki przeważnie nie dotykają również życia prezentowanych osób, Książę Biskup skupia się na portretach osobowości, nie na karierze jednostek (W. Walecki, op. cit., s. 121). 
[...] skoro albowiem stanęliśmy w Kartaginie, przyjęty do jego domu, zastałem gotowe wszystkie sprzęty, których mi tylko do uczciwego obchodzenia się potrzeba było [I, 8, s. 64].

Stanowią one obraz prawdziwej przyjaźni i w taki właśnie sposób postrzega je narrator, który jednak nie pozostawia ich bez komentarza:

Modelusz prawy dobrze czyniących, nie tylko dawał, ale umiał dawać [...] zgoła ten zacny i chwalebny mąż tak umiał korzystać ze wszystkich okoliczności życia swojego, iż stał się ojczyźnie pożytecznym, familii zdatnym, przyjaciołom szacownym, współobywatelom miłym [I, 8, s. 64-65].

Drugiego z bohaterów, którzy mają stać się przykładem pozytywnym, poznaje czytelnik poprzez jego dzieje, te jednak również służą podkreśleniu pewnych konkretnych cech osobowości:

Przystał do kupca [...] i po kilkonastej wi ernej panu usłudze przyszedł do tego stanu, iż sam na siebie kupczyć począł. Rozmaite przygody nie zaraz go przywiodły do tej pory, jakiej żądał, przecież, nie tracąc serca, tyle przez statek i cierpliwość zyskał, iż na koniec wyrównał dostatnim. Że czynnością jego nie rządziło łakomstwo [...] skończył handel i osiadł w Rodzie. Tam upatrzywszy sobie nie posażną ani piękną, ale d obrych obyczajów panienkę, wziął ją za żonę [...] Znać było z jego dyskursów wielką e ru d y c ją [wszystkie podkreślenia moje - K.L.], pamięć zaś miał nadzwyczajną [I, 17, s. 90-91];

oraz przez jego wypowiedź, w której określa swoje zasady:

Najprzód kładę za fundament wszystkiego Istność wszechmocną, nieograniczona, pełną dobroci [...] Reguła obyczajności ta u mnie najcenniejsza: być użytecznym [...] Ust strzegę ile możności [...] Kłamstwa w oczach moich nic nie usprawiedliwia [...] Chronię się osobliwości [...] Zbyt by była pochlebna ta sposobu myślenia mojego definicja, gdybym dodał, że to czynię, com sobie przepisał. Jestem człowiek, niedoskonałość jest moim podziałem [I, 17, s. 92-93]. 
Również sposób, w jaki jest ona skonstruowana - zhierarchizowane według ważności wyliczenie najistotniejszych cech, po których następuje krótkie ich objaśnienie, język charakteryzujący się jasnością, precyzją, dążeniem do ekonomiczności, samo zakończenie wreszcie, w którym bohater zastrzega swoją słabość - należy do wzorca, jaki konstruuje autor i przedstawia opowiadacz.

Co do charakterystyk bohaterów rzeczywistych, to, jak już wspominaliśmy, wyróżnić możemy ich trzy typy. Pierwszy to charakterystyki idealizujące. Wbrew pozorom nie jest ich wcale mało. Do grona ludzi, których narrator stawia za wzór, zaliczają się Ptolomeusz, Amilkar, Hannibal, Lukullus, Attyk, Wergiliusz i wielu innych. Najwięcej uwagi poświęca dwóm z nich - Hannibalowi i Lukullusowi, oni obaj natomiast prezentują modele dwóch różnych ról człowieka. Przyjrzyjmy się pokrótce pierwszemu z nich.

Narrator przedstawia jak kronikarz - opowiadając jego dzieje. Mniej przy tym uwagi Hannibala zwraca na czas, gdy podbijał Rzym i podchodził pod Wieczne Miasto, traktując te wydarzenia raczej jako okazję do polemiki z dziejopisami starożytności, natomiast skupia się na jego postawie po klęsce:

[...] jeszcze by się dłużej trzymał, gdyby go powtórzone rozkazy nie zaszły, żeby szedł na obronę ojczyzny [...] W tym urzędzie dał dowody wielkiej doskonałości. Prawa, które ustanowił, były zbawienne i do aktualnej sytuacji przystosowane. [I, 12, s. 74-75].

Dalsze dzieje bohatera, jego nieustanna walka przeciw Rzymianom, już nie na polu bitwy, ale na dworach królów, gdzie żył jako zbieg, w końcu śmierć, do której zmusili go zawzięci przeciwnicy to właśnie według Grumdryppa zasługiwało na szacunek i uznanie tak dalece, że podejmował dyskusję ze wszystkimi źródłami historycznymi, które przedstawiały tę postać:

[...] że zaś najwięcej przez Rzymiany doszła potomność wieść o jego czynach, oddawać, prawda, musieli niekiedy hołd prawdzie, tam gdzie była oczewista, ale też gdzie go oczernić mogli, nie żałowali czernidła [I, 13, s. 78]. 
Nie sposób nie zauważyć, że narrator prezentuje go przede wszystkim jako wzór „człowieka polityki” - prawodawcę zaangażowanego w rozwój państwa, poświęcającego wszystkie siły na jego obronę, chwytającego się wszelkich sposobów, aby zapewnić mu dostatek i bezpieczeństwo (wśród tych sposobów znalazła się niepotępiona przez opowiadacza wojna najeźdźcza). Hannibal i jego ojciec stają się reprezentantami cech, które wykształcić w sobie powinni również czytelnicy Księcia Biskupa nawet, jeśli ich wysiłki również mają zostać skazane na niepowodzenie. Aluzja do stanu Rzeczpospolitej w słowach:

Prawa, które ustanowił, były zbawienne i do aktualnej sytuacji przystosowane. [I, 12, s. 74],

jest dość wyraźna, a potrzeba ludzi światłych, którzy umieliby dać właśnie do ,aktualnej sytuacji przystosowane” prawa, by wzmóc siły ojczyzny - oczywista. Dlatego właśnie na kartach powieści pojawia się wzór wodza i prawodawcy, nawet jeśli taki model życia obcy jest i narratorowi, i autorowi.

Z Lukullusem jest przeciwnie - jest to wzorzec człowieka prywatnego, wycofanego z rozgrywek politycznych, intelektualisty żyjącego we własnym zaciszu, oddającego się sztuce i nauce, wspierającego kulturę:

Dwór jego był liczny i okazały, ale wybór osób czynił największy honor panu. Cokolwiek najcelniejszych w każdym kunszcie znaleźć się mogło rzemieślników, wszyscy się garnęli do niego, wszyscy się doskonalili pod jego okiem, przezornym i bystrym [I, 19, s. 97-98].

I znów uwaga narratora skupia się na późniejszym, zdawałoby się mniej ciekawym okresie życia bohatera, jego służbę publiczną streszcza w jednej, niezbyt szczegółowej relacji. W przeciwieństwie do Hannibala nie jest jednak Lukullus charakteryzowany przede wszystkim przez polemikę. Grumdrypp, przedstawiając odbiorcy sposób życia bohatera, wartościuje pozytywnie jego postępki i ukazuje go jako 
wzór do naśladowania (,pod okiem przezornym i bystrym”, „,najcelniejszy, największy").

Oczywiście są również bohaterowie negatywni, prezentowani czytelnikowi za pomocą tej właśnie metody - poprzez opowiadanie o ich życiu, dziełach, jakich dokonali, poprzez polemikę ze źródłami historycznymi, przedstawiającymi ich w inny, często wyidealizowany sposób, poprzez przytaczanie ich słów wreszcie. Najdoskonalej, z postaci w końcowym rozrachunku ocenionych negatywnie, model ten realizuje Aleksander. Trzeba jednak podkreślić, że Grumdrypp nigdy nie skupia się na umniejszaniu ich zasług, ani na dowodzeniu, że nie zrobili czegoś, co zrobili. Jedyne, co podlega przekształceniu, to sposób interpretacji tych faktów.

Wyżej wymienione charakterystyki cechują się przede wszystkim tym, że większa ich część oparta jest na postaciowaniu pośrednim, narrator nie wymienia wprost konkretnych właściwości postaci, ale pozwala je wywnioskować, sugeruje je. Jest jednak w Historii wiele charakterystyk bezpośrednich, ujętych w zwarte „obrazki”, podsumowujących wiedzę opowiadacza o danej osobie. Przeważnie są one ambiwalentne lub negatywne. Najlepszym, bo najwyraźniejszym, najczystszym przykładem takiego prezentowania bohaterów jest ,galeria” stołowników Augusta i przyjaciół Lukullusa:

Wkrótce po naszym przyjeździe odwiedził go Cycero. Gdym mu był prezentowany, zaraz na pierwszym wstępie poznałem, iż próżna chwała była namiętnością jego panującą [...] Katon, nie tak wymowny, nie tak gadatliwy jak Cycero, kiedy chciał na moment zaniechać ponurej swojej reprezentacji, miłym był w posiedzeniu [...] cenzor ostry, krytyk niebaczny, ganił wszystko, co mu się nie podobało; nie podobało mu się zaś to wszystko, co nie on czynił. [...] W posiedzeniu ustawicznie zamyślony, ponury, dotkliwy, Pompejusz mało mówił, ale roztropnie. Cezar, miły, uprzejmy, towarzyski, i dobrze mówił, i to, co mówił, z ust jego wychodziło z niezwyczajną jakowąś przyjemnością [I, 19, s. 98-100].

W ten sposób opisywani są ludzie wielcy, będący niejednokrotnie źródłem odwołań w epoce oświecenia. Warto zwrócić uwagę na fakt, że narrator zawsze prezentuje sposób zachowania się w towarzystwie, 
postępowania z innymi. Istotną rzeczą, którą chciał przekazać swojemu odbiorcy, była metoda wartościowania, powoływanie się na zdrowy rozsądek, który każe przypuszczać, że najlepsi ludzie mają swoje słabostki. Skłonność Księcia Biskupa do demityzacji będzie miała możliwość jeszcze się odsłonić. Powyższy sposób charakteryzowania stosuje jednak przeważnie wobec postaci, które ocenia ambiwalentnie, jakby uważał, że różnicę między złem a dobrem odsłaniają tylko czyny i słowa.

Kolejnym środkiem, który stosuje narrator, by przerwać tok akcji i zwrócić myśl czytelnika ku nowemu zagadnieniu, jest skracanie dystansu. Wspominaliśmy o tym przy okazji dystansu opowiadacza wobec opowiadanej historii. Pamiętać należy o tym, że jest to również sposób wprowadzenia nowych wątków myślowych i nauk moralnych. Wyjąwszy te sytuacje, gdy zmniejszenie dystansu służy analizie przeżyć bohatera, związanej z przełomową dla niego sytuacją jest ono stosowane przeważnie, by skonstruować „scenkę”, krótki epizod, z którego czytelnik czerpać ma naukę:

Filip, lekarz ten, który go [Aleksandra - przyp. mój, K.L.] po owej kąpieli w Cydnie do zdrowia przyprowadził, wszedł raz do sali bankietowej i zaczął nawracać do wstrzemięźliwości Aleksandra. Ten, trzymając w ręku kielich wybornego wina, przedsięwziął nawrócić Filipa. Skończyło się na tym, iż i króla, i doktora od stołu wyniesiono; nazajutrz legli obydwa. Doktor, nieprzyzwyczajony, leżał dwa dni bez pamięci; Aleksander, wyszumiawszy się nieco, zaczął pić w najlepszą, i tak dobrze, iż, powtórnie zaniesiony na łóżko już z niego nie wstał [I, 3, s. 53-54].

Całość aż prosi się o morał: pijaństwo szkodzi, najważniejsze jest znać umiar. Powiastek takich w tekście jest niewiele, ubarwiaja go jednak, wyraźnie odcinając się od przeważnie suchej i pobieżnej relacji narratora. Niektóre przywodzą na myśl szkice do bajek, inne stwarzają wrażenie anegdotek, wszystkie jednak podporządkowane są celowi pouczającemu, przedstawiają pozytywne i negatywne postawy, wplatają się w krag wartości prezentowany przez opowiadacza. 
Ostatnim wreszcie, najczęstszym i powodującym najwięcej nieporozumień sposobem przerywania fabuły są polemiki z istniejącymi dziełami historycznymi. Punktem wyjścia jest zawsze jakieś wydarzenie z szerszej, historycznej płaszczyzny które zostało już opisane przez któregoś z kronikarzy:

Na lat kilka przed śmiercią [Lukullus - przyp. mój, K.L.] umknął się z miasta [...] Stąd Plutarch, wieści publicznych wierny opowiadacz, szeroce opisuje tę ostatnią życia Lukullowego okoliczność [...] powiedając, iż jedna z kochanek, chcąc go nadzwyczajnymi sposoby do siebie przywiązać, dała mu filtrum w napoju, które potem stało się przyczyną pomieszania rozumu. [I, 20, s. 102];

Po przywołaniu tego typu zdarzeń obala to, co uważa za fałsz i wymysł za pomocą argumentów, które wypływają z zastosowania wobec powieści kronikarzy zdrowego rozsądku:

Rzecz dziwna, że człowiek roztropny, pisarz znamienity, a do tego filozof, takowe baśnie plecie. Siedemdziesięcioletni starzec nie myśli o kochankach, a gdyby je był miał, naówczas gust jego wyborny nie takie by wybierał, które by do przypodobania się musiały czarów zażywać [I, 20, s. 102].

Zwykle w swoich polemikach z kronikarzami przyświeca narratorowi jeden cel - prawda historyczna. Jeśli jednak zastanowimy się nad wolą autorska, odkryjemy trzy powody, dla których podejmuje on dyskusję z dotychczasowym dorobkiem piśmiennictwa historycznego. Pierwszy, którego przykład mamy powyżej, to oczyszczenie z zarzutów postaci, które chciałby prezentować jako wzorcowe. Podobną taktykę stosuje wobec Hannibala. Zdarza się też, że broni takich historycznych bohaterów, którzy bynajmniej nie zdobywają sobie jego sympatii, na przykład Nerona przed pogłoskami, jakoby spalił Rzym dla kaprysu odbudowania go piękniejszym [II, 2]. Można powiedzieć, że w takich przypadkach rzeczywiście dba o prawdę historyczną.

Drugim powodem podejmowania polemiki jest „rewizjonizm”, czyli przedstawienie wykreowanego przezeń narratora jako rzeczywistego świadka wydarzeń historycznych, stąd właśnie, już cytowa- 
ne, spory o dokładną liczbę słoni, koni i piechoty, które skądinąd znakomity Paul Cazin potraktował zbyt poważnie ${ }^{22}$. Takich polemik jest mało i służą one wyłącznie literackiej grze w prawdopodobieństwo nieprawdopodobnego, mają jednocześnie zgodnie z zamiarem narratora - uwiarygodniać, a zgodnie z zamiarem autora - podważać funkcję Grumdryppa jako naocznego świadka.

Ostatni wreszcie powód do dyskusji z dziejopisami to po prostu odarcie ich dzieł ze wszystkich zmyśleń i zafałszowań niezgodnych ze zdrowym rozsądkiem:

Batalia pod Arbellą od Kurcjusza i Plutarcha inaczej jest opisana [...] Wełdug ich powieści siedział Dariusz na wozie złotym, stały posagi z drogich kruszców w kraju, gdzie przez religię magów reprezentacje takowe były zakazane; zobaczył unoszącego się orła nad Aleksandrem wieszczek, który był na odwodzie. Aleksander nie był nabożny, wieszczkowie tamtejszych wieków, zwyczajnym duchowieństwa trybem nie byli odważni. Kto widział batalie, wie dobrze, iż w kurzu i zamieszaniu nie tylko jednego, ale całego stada orłów postrzec by było trudno. Ptastwo zgiełk i wrzawa straszy. Orzeł, choć go królem innych nazywają, tak wtenczas ucieka jako i wrona. Wszystkie te złączone razem okoliczności sprzeciwiają się bajce, prawda, że zabawnej, ale niedobrze wymyślonej [I, 5, s. 52-53].

Posługując się żartem i ironią, odwołując do racjonalnych przesłanek, traktując z pobłażaniem, ośmiesza Książę Biskup legendy związane z najistotniejszymi bohaterami i czynami starożytności i początków państwa polskiego:

[...] obróciwszy się Lech do swoich [...] pobudzał ich do odwagi i cierpliwości obiecując żyzne siedliska i zdobycz obfitą [...] Ruszyło więc ochotnie nie tak wojsko, jak bardziej thum rozmaitego gatunku z żonami, dziećmi i bydłem [...] i jeżeli nazwać można miastem namioty

22 „Nasz «naoczny świadek» obala twierdzenia Quinte-Curce’a dotyczące liczby słoni, miejscowych zwyczajów, braminów i wielu innych rzeczy. Podobną krytykę uprawia przez wieki, w różnych państwach, aż do czasów panowania Bolesława Chrobrego" (cyt. za: P. Cazin, Książę biskup warmiński Ignacy Krasicki 1735-1801, tłum. M. Mroziński, posłowie i bibliografia Z. Goliński, Wydawnictwo Pojezierze, Olsztyn 1986, s. 196). 
i budy chruściane, powiem naówczas z Kadłubkiem i Długoszem, że miasto założył [III, 5, s. 153].

Stało się to przyczyną licznych nieporozumień zarówno wśród ówczesnych, jak i wśród współczesnych czytelników Historii. Rozważając przyczyny, dla których Krasicki podejmuje swoje polemiki, zwykło się mówić o rewizjonizmie historycznym ${ }^{23}$. Wydaje się to jednak nie do końca trafne, przede wszystkim ze względu na charakter narratora. Rewizji mógłby dokonać albo rzeczywisty świadek, a takim przecież Grumdrypp nie jest, przeciwnie, Książę Biskup podejmuje liczne starania, by nie był on wiarygodny, albo badacz w oparciu o rzeczywiste dokumenty, a przecież większość z tych, na które powołuje się bohater, jest fikcyjna. Wspominaliśmy już o tym, że zadaniem czytelnika jest wyrobienie w sobie krytycznego podejścia do źródeł, racjonalnego myślenia i ostrożności wobec przekazów, tym większej, że zawsze są one subiektywne. Założyć jednak można, że autorowi przyświecał jeszcze jeden cel i nie bez przyczyny większa część księgi trzeciej poświęcona Polsce składa się właśnie z polemik z autorytetami historiografii. Nie kierowała Księciem Biskupem oświeceniowa niechęć do baśniowości, widział w niej jednak zagrożenie dla reform, proponowanych przez obóz królewski. W podaniach o początkach tkwiły bowiem korzenie ówczesnych stosunków społecznych, szlachta wywodziła się z Rzymu - władcy całego cywilizowanego świata, co fundowało jej wyjątkową pozycję zarówno w społeczeństwie polskim, jak i wobec innych narodów. Ten mityczny rodowód mógł być traktowany jako jedna z przeszkód w procesie przemian w strukturze państwa, uznaniu praw mieszczan, zmianie stosunku wobec chłopów. Niekwestionowanym wzorem dla sarmaty byli na polu bitwy Aleksander, na mównicy - Cyceron. Demityzując przeszłość, walczył Książę Biskup o przyszłość, sprzeciwiał się przesądom, wierząc, że jedyna wartość czy jednostki, czy narodu wynika z tego, czym jest i jakimi wartościami się kieruje.

Na koniec wypada wspomnieć o jeszcze jednym środku podawczym - o wypowiedziach postaci. Nie jest ich w tekście wiele. Dialo-

23 Por. choćby cytowana już opinia Cazina czy tytuł jednego z rozdziałów wstępu Klimowicza. 
gi niemal się nie zdarzają, a i monologi są jedynie zmianą podmiotu mówiącego, przekazywane treści nie sprzeciwiają się bowiem idei całości. Nie ma zresztą czemu się dziwić, bohaterowie, jako przynależni do świata przedstawionego, interesują narratora jedynie jako ucieleśnienia pewnych idei, cech, sposobów postępowania. Jak już podkreślaliśmy, Historia opiera się na zawartości ideowej właśnie, a nie na mimetyzmie. Ciekawą stroną wypowiedzi jest ich różnorodna funkcja w powieści. Służą one charakterystyce, jak przytaczany już zbiór zasad Leontiusa [I, 17], pełnią rolę scenek, na co przykładem może być opowieść Ptolomeusza o Diogenesie [I, 4], są nawet polemikami [II, 4], wreszcie służą charakterystyce bohaterów (wypowiedzi Hanibala, Lukullusa i innych) lub przekazują jakąś istotną myśl. Przykładem na to ostatnie może być historia upadku Galii opowiadana narratorowi przez druida Astiorynksa [II, 4, s. 132]. Zrelacjonowana ustami uczestnika tragedii, musiała wywierać większe wrażenie, niż gdyby podją ją kosmopolita-Grumdrypp i być może dlatego właśnie jest on wyłącznie słuchaczem. Nie sposób pomylić się tutaj również co do intencji XBW, który wskazuje niemalże wprost potrzebę zmiany sposobu myślenia i rządzenia w kraju swoich współczesnych.

Wszystkie omówione wyżej zabiegi zmierzają do stworzenia właściwej płaszczyzny, na której toczy się „,akcja”, czyli dyskusja o najważniejszych zagadnieniach - o tym, jakimi wartościami należy kierować się w życiu nie tylko po to by być szczęśliwym, lecz także by móc wywiązać się ze swoich obowiązków względem innych ludzi i względem kraju. Nie jest zresztą Historia tak ponadnarodowa, jak zwykło się o niej myśleć, przeciwnie, sprawa polska poruszana jest w niej na wiele sposobów: nieustanne aluzje do aktualnej sytuacji, próba „wydyskutowania” już - a nie wychowania, jak w pozostałych powieściach XBW - dobrego obywatela, walka z mitami leżącymi u podłoża konserwatyzmu i ksenofobii - wszystko to sprawia, że wpisuje się ona w reformatorskie działania Księcia Biskupa. W przeciwieństwie do swoich poprzedniczek jest jednak ponadstanowa, jej adresatem nie jest ziemianin, lecz każdy wykształcony, inteligentny i myślący człowiek. 